\title{
TOXICITY OF PHTHALODINITRILE AND TETRACHLOROPHTHALODINITRILE
}

\author{
I. ACUTE TOXICITY IN MICE
}

Hiroshi YOSHIKAWA and Kiyoyuki KAWAI

National Institute of Industrial Health, Kizuki-Sumiyoshi, Kawasaki

(Received April 25, 1966)

\begin{abstract}
An acute toxicity of phthalodinitrile and tetrachlorophthalodinitrile in mice was investigated. Isomers of the both compounds were examined and significant differences were noticed in their $\mathbf{L D}_{50}$ values as well as in the symptoms of acute intoxications. The respective intraperitoneal $\mathrm{LD}_{50}$ of o-, m-, and p-phthalodinitrile were $34.5,481.3$ and $698.6 \mathrm{mg} / \mathrm{kg}$, and those of $\mathrm{o}$-, $\mathrm{m}$-, and p-tetrachlorophthalodinitrile were $66.4,2.5$ and $1581.3 \mathrm{mg} / \mathrm{kg}$. From the results obtained, it was suggested that these compounds had different toxic properties.
\end{abstract}

In recent years, repeated occurrences of epilepsy like attacks have been noticed among the workers in manufactories handling o-phthalodinitrile, which has been used as an intermediate of a dye, phthalocyanine blue. Recently, pilot manufacture of o-tetrachlorophthalodinitrile, used as intermediate of phthalocyanine green dye, has begun. Moreover, m-phthalodinitrile and $\mathrm{m}$-tetrachlorophthalodinitrile are also planned to be used as an intermediate of plastics and as an agricultural insecticide respectively.

Under these circumstances, the authors attempted to make experimental studies of acute toxicity of o-phthalodinitrile and o-tetrachlorophthalodinitrile and of these isomers.

\section{EXPERIMENTAL METHODS}

All the compounds used in this experiments, $\mathrm{o}^{-}, \mathrm{m}-$, and $\mathrm{p}$-phthalodinitrile (abbreviated as o-, m-, and p-PDN), and tetrachloro-o-, m-, and p-phthalodinitrile $(\mathrm{o}-, \mathrm{m}-$, and $\mathrm{p}-\mathrm{TCPN})$ were synthesized and supplied through the courtesy of the Laboratory of Sanko Kagaku Co. All compounds studied were white powder, and completely insoluble in water or polyethylene glycol, except for o-PDN, which was slightly soluble in the latter. In these studies on the acute toxicity, therefore, the powder of PDN isomers was suspended in polyethylene glycol. Suspensions of three isomers of TCPN were prepared with olive oil.

Female mice of the ICR strain weighing 20 to $25 \mathrm{~g}$ were used throughout 


\section{H. YOSHIKAWA AND K. KAWAI}

the experiments. For the determination of the median lethal dose, graded doses were administered intraperitoneally, subcutaneously, or orally by a stomach tube using 5 mice at each dose level. All animals were observed for 7 days after the administration and the respective median lethal doses $\left(\operatorname{LD}_{50}\right)$ were calculated according to the method of van der Waerden.1)

\section{RESULTS}

\section{Acute Toxicity of PDN in Mice}

In 5 to 30 minutes after the administration of the o-PDN, the animals suddenly showed raised tail and squeaking followed by an attack of generalized convulsion lasting 10 to 15 seconds. The attacks were repeated several times with 30 to 60 seconds intervals and the death occurred within 5 hours after administration. In the mice received $\mathrm{m}-\mathrm{PDN}$, there occurred similar but less marked attacks of convulsion without any preceding symptoms such as raised tail and squeaking. Administration of p-PDN did not give rise to an outstanding symptom and the animals showed only weakness.

Table 1. Acute toxicity of phthalodinitrile in mice.

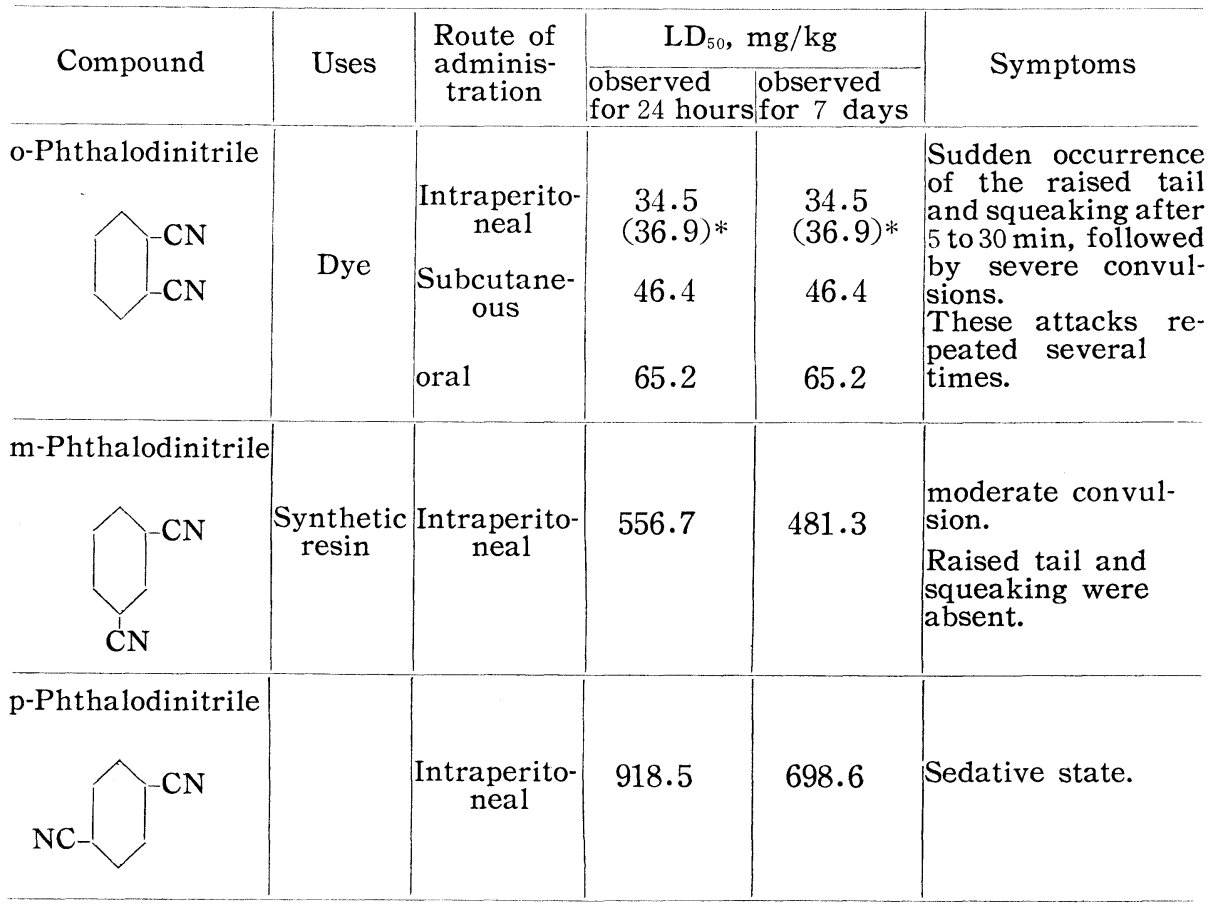

ICR female mice; Phthalodinitrile was dissolved or suspended in polyethylene glycol.

* $\mathrm{LD}_{50}$ value of phthalodinitrile suspended in olive oil.

As shown in Table 1, the intraperitoneal $\mathrm{LD}_{50}$ values of these three isomers 


\section{TOXICITY OF PHTHALODINITRILE COMPOUNDS}

obtained in 7 days observation were $34.5,481.3$, and $698.6 \mathrm{mg} / \mathrm{kg}$ to o-, $\mathrm{m}-$, and p-PDN respectively. As judged from the above $L_{50}$ values, acute toxicity of o-PDN was about 14 times as high as that of $\mathrm{m}$-PDN and about 20 times as high as that of $\mathrm{p}-\mathrm{PDN}$. Also, from the $\mathrm{LD}_{50}$ values in 24 hours and 7 days observation after the administration, similar $L_{50}$ values were obtained in o-PDN, but the $\mathrm{LD}_{50}$ values of the other two isomers tended to decrease from 24 hours to 7 days. That is, animals administered with o-PDN die within brief duration but animal injected with $\mathrm{m}$ - and $\mathrm{p}-\mathrm{PDN}$ tends to extend the duration from injected to death, and this tendency was more evident in p-PDN than in $\mathrm{m}-\mathrm{PDN}$.

From the above results, it could be recognized that the acute toxicity of PDN isomers was significantly different each other. The investigations are now in progress in our laboratory to disclose the relationship between the toxicity and the structure of the compounds.

A few data hitherto available on the toxicity of o-PDN were somewhat discrepant. The $\mathrm{LD}_{50}$ of o-PDN given by the Allied Chemical Corporation ${ }^{2)}$ was estimated as $30 \mathrm{mg} / \mathrm{kg}$ in mice through the subcutaneous route and that by Ueda ${ }^{3)}$ was $7.94 \mathrm{mg} / \mathrm{kg}$ under almost the same experimental condition. The data obtained by the present authors coincided with that of the former, but that of Ueda was far lower than ours. In this respect, the acute toxicity of o-PDN was reexamined using the Tween 20 as solvent, which was used by Ueda to emulsify o-PDN. As listed in Table 2, the intraperitoneal $\mathrm{LD}_{50}$ of o-PDN

Table 2. Acute intraperitoneal toxicity of o-phthalodinitrile dissolved in Tween 20.

\begin{tabular}{c|c|c|c|c|c|c}
\hline $\begin{array}{c}\text { Doses of } \\
\text { o-phthalodinitrile, } \\
\text { mg/kg }\end{array}$ & $\begin{array}{c}\text { Numbers } \\
\text { of } \\
\text { mice }\end{array}$ & \multicolumn{4}{|c|}{ Number of dead animals } & $\begin{array}{c}\text { Mortality } \\
\text { rate }\end{array}$ \\
\cline { 3 - 7 } & 1st day & 2nd day & 3rd day & 4th day & \\
\hline 1 & 5 & 0 & 0 & 0 & 0 & $0 / 5$ \\
5 & 5 & 0 & 1 & 0 & 0 & $1 / 5$ \\
10 & 5 & 1 & 2 & 2 & & $5 / 5$ \\
20 & 5 & 1 & 4 & & & $5 / 5$ \\
40 & 5 & 5 & & & & $5 / 5$ \\
\hline
\end{tabular}

$\mathrm{LD}_{50}: 5 \sim 10 \mathrm{mg} / \mathrm{kg}$.

was in the range of 5 to $10 \mathrm{mg} / \mathrm{kg}$, which was significantly lower than that was found using olive oil or polyethylene glycol as solvent. Furthermore, the characteristic attacks of convulsion, which were seen when polyethylene glycol was used as carrier, were also disappeared in the animals received with o-PDN dissolved in Tween 20. These observations allowed us to conclude that the use of the Tween 20 resulted in an apparent enhancement and the modification of the toxicity of o-PDN in intraperitoneal administration. 


\section{H. YOSHIKAWA AND K. KAWAI}

\section{Acute Toxicity of TCPN in Mice}

The mice received intraperitoneal administration of o-TCPN kept quiet with standing hair, and thereafter weakness developed gradually. In the case of m-TCPN, the sedative state became apparent after about 10 minutes and was preceded occasionally by a spastic stretching of the hind limbs. The intraperitoneal injection of p-TCPN caused sedation followed by fluid accumulation in the peritoneal cavity which became marked after 3 to 4 days. Attacks of convulsion and other prodromal signs which were observed in PDN compounds were entirely absent in these chlorinated derivatives.

The results obtained with TCPN compounds were summarized in Table 3. Respective $\mathrm{LD}_{50}$ values during 7 days after the intraperitoneal administration

Table 3. Acute toxicity of tetrachlorophthalodinitrile in mice.

\begin{tabular}{|c|c|c|c|c|c|}
\hline \multirow{2}{*}{ Compound } & \multirow{2}{*}{ Uses } & \multirow{2}{*}{$\begin{array}{l}\text { Route of } \\
\text { adminis- } \\
\text { tration }\end{array}$} & \multicolumn{2}{|c|}{$\mathrm{LD}_{50}, \mathrm{mg} / \mathrm{kg}$} & \multirow{2}{*}{ Symptoms } \\
\hline & & & $\begin{array}{c}\text { observed } \\
\text { for } 24 \text { hours }\end{array}$ & $\begin{array}{l}\text { observed } \\
\text { for } 7 \text { days }\end{array}$ & \\
\hline o-Tetrachloro- & Dye & $\begin{array}{c}\begin{array}{c}\text { Intraperito- } \\
\text { neal }\end{array} \\
\begin{array}{c}\text { Subcutane- } \\
\text { ous }\end{array} \\
\text { oral }\end{array}$ & 168.8 & $\begin{array}{r}66.4 \\
3500 \sim \\
13720 \sim \\
19210\end{array}$ & $\begin{array}{l}\text { Sedative state. } \\
\text { Ulcer in the site of sub- } \\
\text { cutaneous injection } \\
\text { after several days. }\end{array}$ \\
\hline $\begin{array}{l}\text { m-Tetrachloro- } \\
\text { phthalodinitrile }\end{array}$ & $\begin{array}{l}\text { Agricul- } \\
\text { tural } \\
\text { insecti- } \\
\text { cide }\end{array}$ & $\begin{array}{l}\text { Intraperito- } \\
\text { neal } \\
\text { oral }\end{array}$ & 3.0 & $\begin{array}{r}2.5 \\
6000 \sim\end{array}$ & $\begin{array}{l}\text { Occasional spastic } \\
\text { streching of hind limbs, } \\
\text { following sedative state. }\end{array}$ \\
\hline $\begin{array}{l}\text { p-Tetrachloro- } \\
\text { phthalodinitrile }\end{array}$ & & $\begin{array}{c}\text { Intraperito- } \\
\text { neal }\end{array}$ & 2790.7 & 1581.3 & $\begin{array}{l}\text { Sedative state, and } \\
\text { marked fluid accumu- } \\
\text { lation in the peritoneal } \\
\text { cavity after } 3 \text { to } 4 \text { days. }\end{array}$ \\
\hline
\end{tabular}

ICR female mice; Tetrachlorophthalodinitrile was suspended in olive oil.

of o-, m-, and p-TCPN were 66.4, 2.5, and $1581.3 \mathrm{mg} / \mathrm{kg}$. Among three isomers, again, there were marked differences in their acute toxicity, which might be related to their structure. m-TCPN appeared to be the most toxic in this group and the toxicity declined in the order of $\mathrm{m}-$, o-, and p-TCPN. Remarkable differences in acute toxicity were also noticed on the route of administration. For instance, $\mathrm{m}$-TCPN was a highly toxic substance in the case of intraperito- 


\section{TOXICITY OF PHTHALODINITRILE COMPOUNDS}

neal injection giving $2.5 \mathrm{mg} / \mathrm{kg}$ of $\mathrm{LD}_{50}$, but the toxic effect caused by oral administration was very mild and oral $\mathrm{LD}_{50}$ of $\mathrm{m}$-TCPN was above $6 \mathrm{~g} / \mathrm{kg}$.

\section{DISCUSSION}

Increasing industrial use of PDN and TCPN necessitated us to learn more detailed information about the toxic properties of these substances. In this preliminary experiments in mice, it was clearly demonstrated that some of these isomers were highly toxic as judged by the data so far obtained. At the same time, marked differences were noticed in their symptoms of acute intoxication and in their $\mathrm{LD}_{50}$ values among three isomers of both PDN and TCPN compounds. The different toxic properties of these isomers might be related to their molecular structure and its metabolic fate. But at present, we know nothing about their metabolisms.

It should be also mentioned that the use of different solvents could cause significant alteration of the toxicity of o-PDN. The use of Tween 20, used as carrier, resulted in a definite enhancement of the toxic property of o-PDN. From this fact, it should be again emphasized the importance of careful selection of a solvent in a toxicology study, especially if the substances were hardly soluble in water. On the other hand, the importance of this phenomenon should be kept in mind when actural occurrence of intoxication and its prevention comes into considerations.

\section{ACKNOWLEDGEMENT}

The authors wish to express our thanks to the Members of Sanko Kagaku Company for supplying phthalodinitrile and tetrachlorophthalodinitrile, and to Mrs. S. Kurimori, Miss S. Shimizu, and Miss N. Konishi in our Institute for their technical assistance.

\section{REFERENCES}

1) Kajii, T. (1959). Japan. J. Public Health, 6, 290. (in Japanese),

2) Allied Chemical Corporation: Refer to Ueda's report.

3) Ueda, H. (1961). Yokohama Igaku, 11, 1425. (in Japanese), 